\title{
JUAL BELI EMAS SECARA TIDAK TUNAI DITINJAU SECARA HUKUM FIQIH
}

\author{
Kisanda Midisen ${ }^{1}$, Santi Handayani ${ }^{2}$ \\ 1 Universitas Pelita Bangsa, kisanda35@gmail.com \\ 2 Universitas Pelita Bangsa, santihandayani05@gmail.com
}

\section{A R T I C L E I N F O}

\section{Article history:}

Received : 09/03/2021

Revised : 15/03/2021

Accepted: 01/04/2021

\section{Key words:}

Trade; gold; no cash; fixed law

DOI:

Doi.org/10.37366/jespb.v6i01.172

\begin{abstract}
A B S T R A C T
Today's gold is only valued as women's jewelry. As an investment platform. Rotting, buying and selling gold too. Increasingly. easy, on reality buy gold already. The growth from cash to non-cash markets is due to the high interest in investment in gold with the exchange of goods as cash as it is, it raises questions. That have developed in communities of clean and illegitimate laws. This research is a type of library literature research. In research researchers use the normative and textual approach, that is, to examine the problem in an existing framework of values based on texts and Islamic law, government regulation and other texts relating to dalarm discussion. In the study it may be concluded that the unlawful sale of gold was two opinions: the first opinion was haram, it was the view of clerical mayonnaise (mahzhab Hanafi, Maliki, Syafi'i and Hambali) and the second opinion was the mubah, this is the opinion of Ibn Taimiyah and Ibn Qayim, as well as contemporary scholars who agree.
\end{abstract}

\begin{abstract}
A B S T R A K
Emas pada zaman sekarang tidak hanya digemari sebagai perhiasaan kaum wanita melainkan sebagai sarana investasi yang menjanjikan. Jual beli emas juga semakin mudah. Pada realitanya transaksi jual beli emas telah berkembang dari jual beli tunai menjadi tidak tunai disebabkan antusias masyarakat yang besar tertarik untuk investasi dalam bentuk emas. Dengan adanya transaksi jual beli emas secara tidak tunai ini menimbulkan pertanyaan yang berkembang di masyarakat mengenai hukum halal dan haramnya. Penelitian ini merupakan jenis penelitian kepustakaan library (Library Research). Dalam penelitiannya peneliti menggunakan pendekatan normatif dan yuridis tekstual, yaitu meneliti masalah dalam bingkai norma-norma yang ada dengan mendasarkan pada teks yang bersumber dari hukum Islam, peraturan pemerintah dan teks-teks lain yang berkaitan dalam pembahasan. Dalam penelitian ini dapat disimpulkan bahwa jual beli emas secara tidak tunai secara hukum fikih terdapat 2 pendapat yaitu, Pendapat pertama adalah haram, ini adalah pendapat mayoritas ulama (mahzhab Hanafi, Maliki, Syafi'i, dan Hambali) dan Pendapat kedua adalah mubah, ini adalah pendapat Ibnu Taimiyah dan Ibnu Qayim, juga ulama kontemporer yang sependapat.
\end{abstract}

\section{PENDAHULUAN}

Syariah Islam sebagai suatu syariah yang dibawa oleh Rasul terakhir, mempunyai keunikan tersendiri. Setiap aspek kehidupan umat Islam telah diatur dalam Al-Qur'an dan As-Sunnah. Pada hakikatnya agama Islam bukan hanya sebuah ritual ibadah melainkan cara hidup sesuai dengan AlQur'an dan As- Sunnah. Al-Qur'an dan As-Sunnah yang menjadi sumber dan pedoman bagi umat untuk bertindak mengandung ajaran-ajaran tentang akidah dan ajaran tentang syariah. Kemudian, syariah itu sendiri terdiri atas ibadah dan mumalah (Mahmud, 1966: 11-13). Selain hubungan manusia dengan pencipta-Nya, hubungan antar sesama manusia juga telah diatur dengan jelas. Syariah ini bukan saja menyeluruh atau komprehensif, tetapi 
juga universal. Karakter istimewa ini diperlukan sebab tidak akan ada syariah lain yang datang menyempurnakannya.

Komprehensif berarti syariah Islam merangkum seluruh aspek kehidupan, baik ritual (ibadah) maupun sosial (muamalah). Ibadah diperlukan untuk menjaga ketaatan dan keharmonisan hubungan manusia dengan Khaliq-nya. Ibadah juga cara untuk mengingatkan secara kontinu tugas manusia sebagai khalifah-Nya di muka bumi ini. Adapun muamalah diturunkan menjadi rules of the game atau aturan main manusia dalam kehidupan social (Syafi'i, 2001: 4). Hubungan manusia dengan sesama ini memiliki cabang ilmu yang biasa disebut dengan fikih muamalah. Fikih muamalah didefinisikan sebagai hukum-hukum yang berkaitan dengan tindakan manusia dalam perkara harta, misalnya dalam persoalan jual beli, utang piutang, kerjasama dagang, perserikatan kerjasama dalam penggarapan tanah, sewa menyewa dan lain sebagainya (Natadipurba, 2016: 231).

Kaidah fikih mumalah sendiri adalah boleh sampai ada yang mengharamkannya, berbeda dengan ibadah yang pada hakikatnya adalah haram sampai ada dalil yang mengaturnya atau menghalalkannya. Dalam prakteknya di kehidupan sehari hari seseorang melalukan muamalah dengan orang lainnya untuk memenuhi kebutuhannya, Salah satunya adalah jual beli. Jual beli dalam istilah fikih disebut dengan al-bai' yang berarti menjual, mengganti, dan menukar sesuatu dengan sesuatu yang lain. Lafal al-bai' dalam bahasa Arab terkadang digunakan untuk pengertian lawannya, yakni kata asysyira' (beli). Dengan demikian, kata al-bai' berarti jual tetapi sekaligus juga berarti beli (Nasrun, 2000: 111). Sedangkan menurut istilah, jual beli pada intinya adalah suatu perjanjian tukar menukar benda atau barang yang mempunyai nilai sukarela diantara kedua belah pihak, yang satu menerima benda-benda dan pihak lain menerimanya sesuai dengan perjanjian atau ketentuan yang dibenarkan syara' dan disepakati. (Hendi, 2005: 68-69)

Dulu praktek jual beli tidak seperti sekarang yang menggunakan uang kertas sebagai alat pembayaran atau alat tukar, melainkan beberapa keping Dinar atau Dirham yang terbuat dari emas dan perak pada masanya. Dalam sejarah Islam, uang merupakan sesuatu yang diadopsi dari peradaban Romawi dan Persia. Ini dimungkinkan karena penggunaan dan konsep uang tidak bertentangan dengan ajaran Islam. Dinar adalah mata uang emas yang diambil dari Romawi dan Dirham adalah mata uang perak warisan peradaban Persia (Mustafa, 2007: 242).

Emas dan perak pernah dibuat dan berlaku di Indonesia sebagai mata uang resmi sejak abad ke-14 berupa Dinar dan Dirham. Emas dan perak pernah mendominasi pasar-pasar di sebagian besar Nusantara, antara lain di Pasai, Malaka, Banten, Cirebon, Demak, Tuban, Gresik, Gowa dan Kepulauan Maluku. Dinar adalah koin emas berkadar 22 karat $(91,70 \%)$ dengan berat 4,25 gram. Sedangkan Dirham adalah koin perak murni (99,95\%) dengan berat 2,975 gram (Marwan, 2020). Awalnya telah disepakati penggunaan emas sebagai standar global nilai mata uang melalui perjanjian Bretton Woods. Seiring dengan perubahan zaman alat pembayaran berubah menjadi uang kertas yang di cetak sesuai nilai emas yang ada. Ismail Hasyim sebagaimana yang dikutip oleh Ahmad Hasan, menyatakan bahwa uang adalah sesuatu yang diterima secara luas dalam peredaran, digunakan sebagai media pertukaran, sebagai standar ukuran nilai harga, dan media penyimpan nilai, juga digunakan sebagai alat pembayaran untuk kewajiban bayar yang ditunda (Ahmad, 2005: 11).

Walaupun sekarang emas tidak menjadi alat tukar, tetapi sejatinya sampai sekarang emas masih menjadi standar mata uang di dunia karena nilainya yang stabil. Emas dan perak merupakan alat tukar paling stabil yang pernah dikenal oleh dunia. Sejak awal sejarah Islam sampai saat ini, nilai dari mata uang Islam yang didasari oleh mata uang bimetal ini secara mengejutkan sangat stabil. Jika dihubungkan dengan bahan makanan pokok, dahulu harga seekor ayam pada tahun $680^{\prime}$ an adalah satu Dirham emas. Dan saat ini 1.400 tahun kemudian, harga seekor ayam tetaplah satu Dirham emas. Selama 1.400 tahun nilai inflasinya adalah nol. Hal ini sulit ditemukan fenomena yang sama terhadap Dollar atau mata uang lainnya (Marwan, 2020). 
Oleh karena itu orang-orang mulai menggunakan emas sebagai alat investasi jangka panjang. Karena melihat dari segi nilai emas yang stabil, rendahnya resiko, mudahnya pencairan dana membuat masyarakat antusias dalam berinvestasi emas. Adanya antusiasme masyarakat inilah yang membuat para penyedia jasa membuat suatu sistem yang memudahkan masyarakat dalam jual beli ataupun berinvestasi. Sehingga banyak bermunculan produk-produk pada lembaga keuangan yang memberikan kemudahan para nasabah atau masyarakat dalam menabung atau berinvestasi emas. Tetapi yang harus diperhatikan para penyedia jasa dalam prakteknya adalah harus tetap sesuai dengan kaidah fikih mualamah agar dapat terindar dari riba, tidak lebih dari itu tidak ada perbedaan pendapat di kalangan para ulama bahwa serah terima komoditi riba disyaratkan tunai dan disyaratkan sama karena emas merupakan salah satu komoditi ribawi. Riba sendiri adalah sesuatu yang dilarang dalam agama Islam.

Sehubungan dengan hal tersebut, MUI sebagai lembaga yang mempunyai otoritas dalam pembuatan fatwa dalam bidang ekonomi syaiah di Indonesia, memberikan solusi dengan menetapkan fatwa nomor 77/DSN-MUI/V/2010, MUI yang memutuskan bahwa jual beli emas secara tidak tunai, baik melalui jual beli biasa atau jual beli murabahah, hukumnya boleh (mubah, jaiz) selama emas tidak menjadi alat tukar yang resmi (uang) dengan ketentuan harga jual (tsaman) tidak boleh bertambah selama jangka waktu perjanjian meskipun ada perpanjangan waktu setelah jatuh tempo. Salah satu pertimbangan yang digunakan MUI dalam menetapkam fatwa tersebut adalah karena transaksi jual beli emas yang dilakukan masyarakat saat ini seringkali dilakukan dengan cara pembayaran tidak tunai, baik secara angsuran (taqsit) maupun secara tangguh ( tajil $^{\prime}$ ). Setelah adanya fatwa dari MUI ini ternyata tidak serta merta membuat masyarakat tenang dalam bertransaksi jual beli emas secara tidak tunai. Karena dalam hukumnya masih menjadi pertanyaan yang berkembang di masyarakat, tentang hukum halal dan haram jual beli emas secara tidak tunai atau kredit.

\section{Rumusan Masalah}

Berdasarkan uraian pada latar belakang yang telah dijabarkan di atas, maka penulis merumuskan masalah sebagai berikut:

1. Bagaimana hukum jual beli emas secara tidak tunai dalam hukum fikih?

\section{Tujuan Penelitian}

Berdasarkan rumusan masalah di atas, maka penelitian ini bertujuan sebagai berikut:

1. Untuk mendeskripsikan hukum jual beli emas secara tidak tunai dalam hukum fikih.

\section{TINJAUAN TEOIRITIS}

\section{Jual Beli}

Jual beli berasal dari bahasa arab yaitu $b a^{\prime} i$ Jual beli pada intinya adalah suatu perjanjian tukar menukar benda atau barang yang mempunyai nilai sukarela diantara kedua belah pihak, yang satu menerima benda-benda dan pihak lain menerimanya sesuai dengan perjanjian atau ketentuan yang dibenarkan syara' dan disepakati. (Hendi, 2005: 68-69).

Dalam pelaksanan jual beli ada lima rukun yang harus dipenuhi seperti di bawah ini:

1) Penjual. Ia harus memiliki barang yang dijualnya atau mendapat izin untuk menjualnya dan sehat akalnya.

2) Pembeli. Ia disyaratkan diperbolehkan bertindak dalam arti ia bukan orang yang kurang waras, atau bukan anak kecil yang tidak mempunyai izin untuk membeli.

3) Barang yang dijual. Barang yang dijual harus merupakan yang hal yang diperbolehkan dijual, bersih, bisa diserahkan kepada pembeli dan bisa diketahui pembeli meskipun hanya dengan ciricirinya .

4) Bahasa akad, yaitu penyerahan (ijab) dan penerimaan (qabul) dengan perkataan, misalnya, penjual berkata, "Aku jual barang ini kepadamu". Atau ijab dan qabul dengan perbuatan, misalnya penjual berkata, "Aku menjual pakaian ini kepadamu", kemudian 
penjual memberikan pakaian yang dimaksud kepada pembeli.

5) Kerelaan kedua belah pihak; penjual dan pembeli. Jadi, jual beli tidak sah dengan ketidakrelaan salah satu dari dua pihak, karena Rasulullah SAW. bersabda, "Sesungguhnya jual beli itu dengan kerelaan". (HR. Ibnu Majah dengan sanad hasan).

Adapun syarat tidak disahkannya jual beli sebagi berikut:

1) Menggabungkan dua syarat dalam jual beli misalnya pembeli kayu bakar mensyaratkan bisa memecah kayu bakar sekaligus membawanya. Karena Rasulullah shallallahu alaihi wasallam bersabda "dua syarat dalam satu jual beli itu tidak halal" (H.R Abu Dawud dan AtTirmidzi).

2) Mensyaratkan sesuatu yang merusak inti jual beli itu sendiri, misalnya penjual kambing mensyaratkan kepada pembeli bahwa pembeli tidak boleh menjualnya lagi atau pembeli tidak boleh menjualnya kepada Zaid atau tidak boleh menghadiahkannya kepada Amar atau penjual mensyaratkan pembeli meminjamkan sesuatu kepadanya atau menjual sesuatu kepadanya. Karena Rasulullah shallallahu alaihi wasallam bersabda "tidak halal menjual apa yang tidak ada disisimu" (H.R Abu Dawud dan At-Tirmidzi).

3) Syarat batil yang bisa mensahkan jual beli dan membatalkannya. Misalnya, penjual budak mensyaratkan bahwa perwalian (wala') budak yang akan dijual itu menjadi miliknya. Syarat seperti itu batil, namun jual belinya sah. Rasulullah shallallahu alaihi wasallam bersabda "Barangsiapa yang mensyaratkan persyaratan yang tidak ada dalam kitabullah maka batil, kendati 100 persyaratan" (H.R Abu Daud dan Al-Hakim).

\section{Emas}

Emas adalah salah satu logam mulia yang telah terdaftar dalam tabel periodik dengan kode Au (Aurum). Emas bersifat lunak dan mudah ditempa karena kekerasannya hanya berkisar 2,5-3 (skala Mohs). Karakteristik emas yang paling kita kenal adalah kuning mengkilap dan sangat lembek.
Bahkan banyak ahli yang mencoba kemurniaan emas dengan meninggalkan gigitan di logam tersebut. Emas sendiri sangat fleksibel dan dapat dicampur dengan banyak logam lainnya. Bahkan emas dapat menjadi konduktor panas dan listrik yang sangat baik sehingga banyak dijadikan semikonduktor dalam chipset handphone. Berbeda dengan logam lainnya, emas tidak mengenal kata karatan atau korosi.

\section{Jual Beli Tidak Tunai}

Jual beli kredit adalah transaksi jual beli dimana barang diterima pada waktu transaksi dengan pembayaran tidak tunai. Dengan harga yang lebih mahal daripada harga tunai serta pembeli melunasi kewajibannya dengan cara angsuran tertentu dalam jangka waktu tertentu.

Jual kredit dibolehkan dalam Islam sebagaimana hasil keputusan Majma' Al Fiqh Al Islami (divisi fikih OKI), No. 51 (2/6) 1990, yang berbunyi:

"Boleh melebihkan harga barang yang dijual dengan tidak tunai daripada daripada dijual tunai ... dan harganya dicicil dalam jangka waktu yang ditentukan." (Journal Islamic Fiqh Council, vol VII, jilid 2, hal 9)

Fatwa Syeikh Abdul Aziz bin Baz rahimahullah, jual beli kredit hukumnya boleh dengan syarat bahwa lamanya masa angsuran serta jumlah angsuran diketahui dengan jelas saat akad, sekalipun jual beli kredit biasanya lebih mahal daripada jual beli tunai. Hal ini diperbolehkan karena kedua belah pihak mendapat keuntungan dari jual beli kredit. Penjual mendapat keuntungan karena harga barangnya lebih mahal dan pembeli mendapat keuntungan karena mendapat tempo tunggakan pembayaran.

Dalam hukum Islam jual beli kredit dikatakan sah apabila memenuhi beberapa persyaratan. Persyaratan-persyaratan tersebut meliputi:

1) Akad ini tidak dimaksudkan untuk melegalkan riba. Maka tidak boleh jual beli 'inah. Juga tidak boleh dalam akad jual beli kredit dipisah antara harga tunai dan margin yang diikat dengan waktu dan bunga, karena ini menyerupai riba. 
2) Barang terlebih dahulu dimiliki penjual sebelum akad jual beli kredit dilangsungkan. Maka tidak boleh pihak jasa kredit melangsungkan akad jual beli kredit motor dengan konsumennya, kemudian setelah itu ia melakukan akad jual beli, memesan motor dan membelinya ke salah satu pusat penjualan motor lalu menyerahkannya kepada pembeli.

3) Pihak penjual kredit tidak boleh menjual barang yang telah dibeli tapi belum diterima dan belum berada di tangannya kepada konsumen. Maka tidak boleh pihak jasa kredit melangsungkan akad jual beli kredit motor dengan konsumennya sebelum barang yang telah dibelinya dari dealer motor diterimanya.

4) Barang yang dijual bukan merupakan emas, perak atau mata uang. Maka tidak boleh menjual emas dengan cara kredit, karena ini termasuk riba $b a^{\prime} i$.

5) Barang yang dijual secara kredit harus diterima pembeli tunai pada saat akad berlangsung. Maka tidak boleh transaksi jual beli kredit kredit dilakukan hari ini dan barang diterima pada keesokan harinya. Karena ini termasuk jual beli utang dengan utang yang diharamkan.

6) Pada saat transaksi dibuat harga harus satu dan jelas serta besarnya angsuran dan jangka waktunya juga harus jelas.

7) Akad jual beli kredit harus tegas. Maka tidak boleh akan dibuat dengan cara beli sewa (leasing).

8) Tidak boleh membuat persyaratan kewajiban membayar denda, atau harga barang menjadi bertambah jika pembeli terlambat membayar angsuran. Karena ini adalah bentuk riba yang dilakukan oleh orang-orang Jahiliyah di masa Nabi SAW.

\section{Kerangka Pikir}

Untuk mempermudah gambaran yang jelas dan konkret tentang permasalahan yang terkandung dalam konsep penelitian ini, maka perlu dijelaskan makna yang terdapat dalam penelitian ini. Definisi operasional dari judul:
1) Jual beli: Jual beli pada intinya adalah suatu perjanjian tukar menukar benda atau barang yang mempunyai nilai sukarela diantar kedua belah pihak, yang satu menerima benda-benda dan pihak lain menerimanya sesuai dengan perjanjian atau ketentuan yang dibenarkan syara' dan disepakati (Hendi, 2005: 68-69).

2) Emas: Suatu logam mulia yang mempunyai nilai, dan biasa dijadikan standar nilai atau standar mata uang juga sebagai perhiasan.

3) Tidak Tunai: Jual beli dengan cara mengangsur atau dalam masyarakat sering disebut kredit.

4) Hukum Islam: Katetapan atau hukum yang diambil berdasarkan Al-Quran dan As-Sunnah. Dengan metode-metode yang ada dalam syariat Islam.

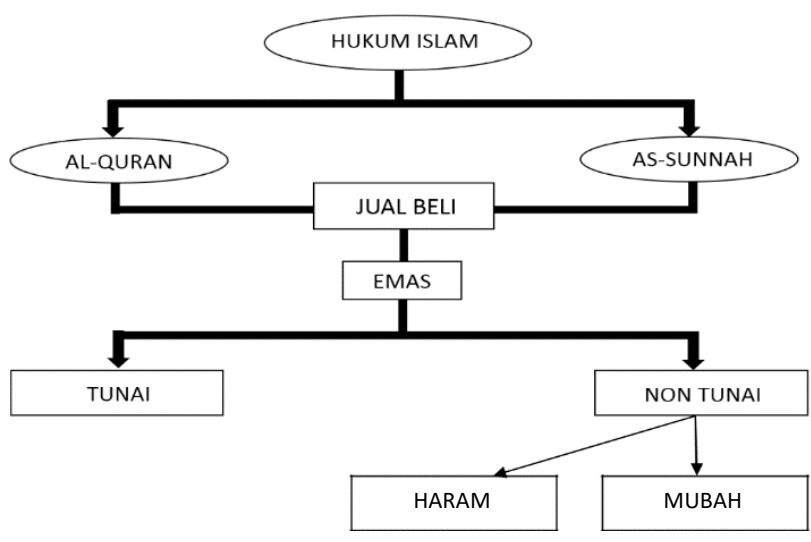

Gambar 1. Kerangka Pikir

\section{METODE PENELITIAN}

Penelitian ini termasuk penelitian kepustakaan (library research) dengan analisis kualitatif deskriptif. Dalam penelitiannya peneliti menggunakan pendekatan normatif dan yuridis tekstual, yaitu meneliti masalah dalam bingkai norma-norma yang ada dengan mendasarkan pada teks yang bersumber dari hukum Islam, peraturan pemerintah dan teks-teks lain yang berkaitan dalam pembahasan. 


\section{HASIL DAN PEMBAHASAN}

Pendapat Ulama Tentang Keharaman Jual Beli Emas Secara Tidak Tunai

1) 'Ijma para Ulama (Mahzhab Hanafi, Maliki, Syafi'i, dan Hambali)

Dari Ubadah bin Shamit R.A bahwa Rasulallahu SAW bersabda:

"Jika emas dijual dengan emas, perak dijual dengan perak, gandum dijual dengan gandum, sya'ir (salah satu jenis gandum) dijual dengan sya'ir, kurma dijual dengan kurma, dan garam dijual dengan garam, maka jumlah (takaran atau timbangan) harus sama dan dibayar kontan (tunai). Jika jenis barang tadi berbeda, maka silakan engkau membarterkannya sesukamu, namun harus dilakukan secara kontan (tunai)." (HR. Muslim no. 1587)

Ukurannya bila ditukar dengan komoditi yang sejenis. Dan bila berlainan jenis dan masih satu 'illat disyaratkan tunai saja berdasarkan sabda Nabi SAW tersebut. Ijma' ini dinukil oleh An-Nawawi (AlMajmu' jilid X, hal. 40).

2) Ibnu Mundzir

Ibnu Munzir berkata para ulama sepakat bahwa dua orang yang saling menukar uang bila berpisah sebelum melakukan serah terima uangnya maka transaksinya tidak sah (Al-Ijma' hal. 92).

\section{3) Al Ghazali}

Al Ghazali wafat $505 \mathrm{H}$, berkata orang yang melakukan transaksi riba pada Dinar dan Dirham sungguh ia telah kufur nikmat dan berbuat kezaliman. Karena Dinar dan Dirham diciptakan sebagai media dan bukan tujuan, maka bila diperdagangkan dia akan menjadi komoditi dan tujuan, hal ini ini bertentangan dengan tujuan semula uang diciptakan. Oleh karena itu, tidak dibolehkan menjualnya berjangka (tidak tunai), hal ini dapat mencegah orang-orang untuk menjadikannya sebagai komoditi dan para pedagang tidak akan melakukan hal ini untuk meraup keuntungan (Ihyaa' Ulumuddin, jilid IV, hal. 88).

\section{4) Ibnu Hubairah}

Ibnu Hubairah wafat tahun $560 \mathrm{H}$, berkata umat Islam telah sepakat bahwa tidak boleh menukar emas dengan emas, atau perak dengan perak, baik yang masih berbentuk bahan baku, berbentuk mata uang, ataupun berbentuk perhiasan dengan cara tidak tunai dan tidak sama beratnya. Ini merupakan riba nasiah dan riba fadhl. Dan umat Islam juga sepakat bahwa boleh menukar emas dengan perak dengan ukuran yang berbeda akan tetapi haram dilakukan dengan cara tidak tunai. (Ikhtilaf $\mathrm{Al}$ Aimmah Al Ulama, jilid 1, hal 358).

\section{5) Ibnu Zubair}

Ibnu Zubair wafat tahun $741 \mathrm{H}$, berkata para ulama sepakat bahwa haram hukumnya menukar emas dengan perak, atau emas dengan emas, atau perak dengan perak, baik berbentuk bahan baku ataupun telah diubah menjadi perhiasan dengan cara tidak tunai. Akan tetapi serah terima kedua barang wajib dilakukan tunai. (Al Qawanin Al Fiqhiyyah, hal 275).

6) Rabithah Alam Islami (Muslim World League)

Untuk 2 komoditi yaitu emas dan perak yang merupakan mata uang di masa Nabi SAW dapat disamakan dengan mata uang sekarang sebagaimana hasil keputusan para ulama se-dunia yang tergabung dalam Rabithah Alam Islami (Muslim Word League) dalam muktamar ke V di Mekkah pada tahun 1982, yang berbunyi, "Berdasarkan penelitian yang diajukan kepada Majelis Lembaga Fikih Islam tentang uang kartal (real money) serta hukumnya menurut syariat, setelah ditelaah dikaji dan didiskusikan oleh para anggota majelis, maka diputuskan sebagai berikut:

Pertama, berdasarkan bahwa asal uang adalah emas dan perak dan berdasarkan illat berlakunya riba pada emas dan perak adalah mutlaq tsammaniyah (nilai tukar mutlak) menurut pendapat ulama yang terkuat. Dan berdasarkan pendapat ulama bahwa mutlaq tsammaniyah tidak terbatas pada emas dan perak saja, sekalipun statusnya adalah logam mulia yang menjadi patokan. Dan berdasarkan bahwa uang kartal pada masa sekarang dianggap sebagai alat tukar, menggantikan emas dan perak, dan sebagai alat 
ukur harga, karena tidak ada lagi orang yang menggunakan emas dan perak sebagai alat tukar. Dan uang kartal telah dipercaya orang untuk menginvestasikan, dan menyimpan hartanya, serta digunakan sebagai alat pembayaran kewajiban, sekalipun nilai uang kartal bukan zat fisiknya akan tetapi nilainya berasal dari kepercayaan pengguna untuk dipindahtangankan, dari hal itulah sifat tsamaniyah (nilai) dihasilkan. Dan karena pendapat yang terkuat tentang illat riba pada emas dan perak adalah mutlak sama mutlak sama Nia dan hal itu terdapat pada uang kartal. Berdasarkan alasanalasan di atas maka majelis memutuskan bahwa uang kartal adalah uang yang berdiri sendiri titik hukum uang kartal sama dengan uang emas dan perak maka wajib mengeluarkan zakat dari uang kartal. Riba fadhl dan nasiah juga berlaku pada uang kartal layaknya emas dan perak maka hukumhukum yang berkenaan dengan emas dan perak juga berlaku pada uang kartal itu.

Kedua, uang kartal adalah uang yang berdiri sendiri sama seperti uang emas dan perak terdiri dari berbagai jenis, sesuai dengan jenis negara yang mengeluarkannya. Maka mata uang Saudi satu jenis, mata uang Amerika jenis yang lain, dan seterusnya setiap mata uang sebuah negara merupakan jenis tersendiri. Dengan demikian, dapat terjadiriba fadhll dan nasi' ah pada setiap mata uang sebagaimana terjadi di bafadal dan nasihat pada uang emas dan perak. Konsekuensi dari keputusan ini adalah sebagai berikut :

a. Tidak boleh menukar satu mata uang dengan mata uang negara yang lain atau dengan emas dan perak dengan cara tidak tunai. Misalnya menukar Riyal Saudi dengan mata uang lain dengan cara tidak tunai (serah terima kedua mata uang tidak di tempat akad berlangsung) tidak dibolehkan.

b. Tidak boleh menukar uang menjadi pecahan dan mata uang dengan nominal yang berbeda sekalipun dilakukan tunai. Misalnya, satu lembar nominal S.R. 10.00 dengan 11 lembar nominal S.R.1.00 tidak boleh.

c. Boleh menukar mata uang yang berlainan jenis berbeda nominalnya dengan syarat berlangsung tunai. Misalnya menukar 1 Dolar
Amerika dengan 3 Riyal Saudi dengan cara tidak tunai dibolehkan

Ketiga, wajib mengeluarkan zakat uang kartal bila nominalnya senilai salah satu nishab zakat emas atau perak, atau menggenapkan nishab bersama harta yang lain seperti harta perniagaan.

Keempat, boleh menjadikan uang kartal sebagai modal pada akad jual beli salam dan sebagai modal dalam berserikat. Wallahu a'lam.

7) Keputusan No. 21 (9/3) Muktamar ke III para ulama dunia di bawah OKI

Keputusan nomor 2 (9/3) yang berbunyi "Majlis Lembaga Fikih Islam menetapkan bahwa uang kartal mempunyai kriteria tsammaniyah (harga/nilai). Hukumnya sama dengan hukumhukum yang telah dijelaskan syariat tentang emas dan perak. Riba dapat terjadi pada uang kartal. Uang kartal terkena zakat dan dapat dijadikan modal dalam akad salam serta seluruh hukumhukum yang telah ditentukan.

8) Fatwa Kerajaan Arab Saudi No. 3211

Kasus yang pernah ditanyakan kepada lembaga fatwa Kerjaan Arab Saudi, nomor fatwa 3211, yang berbunyi:

Soal: Seorang pelanggan datang ingin membeli emas ke tokoku, ia hanya membawa uang tunai cukup untuk bayar DP saja, mohon emasnya disisihkan dan ini uangnya! Nanti saya datang untuk melunasinya". Beberapa waktu kemudian ia datang melunasi dan menerima emas tersebut. Apa hukum jual-beli ini?

Jawab: Jual beli ini tidak dibolehkan, karena serah terima barang tidak tunai". (Fatawa lajnah daimah, jilid XIII, hal 476).

Soal: Terkadang pemilik toko emas membeli emas dalam jumlah besar dari salah satu agen emas di luar kota melalui telepon, dan jenis emas yang dipessan jelas. Setelah terjadi kesepakatan harga, kemudian pembeli mengirim uang kepada penjual melalui transfer rekening bank, apakah transaksi ini dibolehkan, atau apayang harus dilakukan?

Jawab: transaksi ini hukumnya tidak boleh, karena serah terima barang emas dan uang tidak tunai, 
padahal keduanya adalah komoditi riba. Transaksi ini termasuk riba nasi'ah, hukumnya haram. Solusinya, pada saaat uang diterima, akad jual beli diulang kembali agar akad berlangsung tunai. (Fatawa lajnah daimah, jilid XIII, hal 475).

9) Maj'ma Fiqh Al Islami (divisi fikih OKI)

Maj'ma Fiqh Al Islami (divisi fikih OKI) dalam muktamar di Abu Dhabi pada tahun 1995 memutuskan, "Menekankan kembali pendapat para ahli fikih yang melarang menukar emas perhiasan dengan yang tidak perhiasaan dengan ukuran yang tidak sama".

10) Accounting And Auditing Organization For Islamic Financial Institutions (AAOIFI)

Panduan perbankan syariah internasional AAOIFI yang menyatakan dalam Bab: Al Murabahah lil Amir Bisysyira', No. 2/2/6, yang berbunyi, jual beli murabahah tidak tunai tidak boleh dilakukan pada emas atau perak, atau mata uang. (Al Ma'ayir Asyar'iyyah, hal 93).

\section{Pendapat Ulama Tentang Kehalalan Jual Beli Emas Secara Tidak Tunai}

1) Ibnu Taimiyah dan Ibnu Qayim

Ibnu Taimiyah, berkata "Boleh melakukan jual beli perhiasan dari emas dan perak dengan jenisnya tanpa syarat harus sama kadarnya (tamatsul), dan kelebihannya dijadikan sebagai kompensasi atas jasa pembuatan perhiasan, baik jual beli itu dengan pembayaran tunai maupun dengan pembayaran tangguh, selama perhiasan tersebut tidak dimaksudkan sebagai harga (uang)."

Ibnu Qayyim menjelaskan lebih lanjut: "Perhiasan (dari emas atau perak) yang diperbolehkan, karena pembuatan (menjadi perhiasan) yang diperbolehkan, berubah statusnya menjadi jenis pakaian dan barang, bukan merupakan jenis harga (uang). Oleh karena itu, tidak wajib zakat atas perhiasan (yang terbuat dari emas atau perak) tersebut, dan tidak berlaku pula riba (dalam pertukaran atau jual beli) antara harga (uang) dengan barang lainnya, meskipun bukan dari jenis yang sama. Hal itu karena dengan pembuatan (menjadi perhiasan) ini, perhiasan (dari emas) tersebut telah keluar dari tujuan sebagai harga (tidak lagi menjadi uang) dan bahkan telah dimaksudkan untuk perniagaan. Oleh karena itu, tidak ada larangan untuk memperjualbelikan perhiasan emas dengan jenis yang sama..." (I'lam alMuwaqqi'in: 2/ 247).

\section{2) Fatwa DSN-MUI}

Sebagai salah satu lembaga hukum yang ada di Indonesia MUI juga telah menetapkan fatwa yang berkaitan dengan hukum jual beli emas secara tidak tunai yang menjadi pertanyaan banyak masyarakat. Setelah menimbang dan mengingat beberapa persoalan dan kaidah yang sesuai dengan keadaan saat ini. Berikut ketetapannya berdasarkan pada keputusan Fatwa Dewan Syari'ah Nasional No 77/DSN-MUI/VI/2010 Tentang Jual-Beli Emas Secara Tidak Tunai, sebagai berikut:

"Hukum Jual beli emas secara tidak tunai, baik melalui jual beli biasa atau jual beli murabahah, hukumnya (mubah,ja'iz) selama emas tidak menjadi alat tukar yang resmi (uang). Batasan dan ketentuan:

a. Harga jual (tsaman) tidak boleh bertambah selama jangka waktu perjanjian meskipun ada perpanjangan waktu setelah jatuh tempo.

b. Emas yang dibeli dengan pembayaran tidak tunai boleh dijadikan jaminan (rahn).

c. Emas yang dijadikan jaminan sebagaimana dimaksud dalam poin b tidak boleh dijual.

Di dalam fatwa MUI No. 77/DSN-MUI/V/2010 tentang jual beli emas secara tidak tunai ini, DSNMUI menetapkan bahwa jual beli emas secara tidak tunai baik melalui jual beli biasa atau jual beli murabahah, hukumnya boleh (mubah, jaiz) selama emas tidak menjadi alat tukar yang resmi (uang). Akan tetapi kebolehan tersebut ada ketentunnya yakni harga jual (tsaman) tidak boleh bertambah selama jangka waktu perjanjian meskipun ada perpanjangan waktu setelah jatuh tempo.

Dari beberapa pendapat di atas jual beli emas secara tidak tunai dalam pandangan fiqih ada 2 pendapat. Argumen paling menonjol dalam pendapat ini adalah bahwa uang kertas dan emas merupakan tsaman (harga, uang) sedangkan tsaman tidak boleh diperjual belikan kecuali secara tunai. 


\section{KESIMPULAN}

Secara global, terdapat dua pendapat Ulama tentang jual beli emas dengan uang kertas secara angsuran:

1) Pendapat pertama: Haram.

Ini adalah pendapat mayoritas Ulama, dari mazhab Hanafi, Maliki, Syafi'i, dan Hambali dengan argumen (istidlal) berbeda-beda. Argumen paling menonjol dalam pendapat ini adalah bahwa uang kertas dan emas merupakan tsaman (harga, uang) sedangkan tsaman tidak boleh diperjual belikan kecuali secara tunai. Hal ini berdasarkan hadist 'Ubadah bin alShamit bahwa Nabi Muhammad SAW bersabda, "Jika jenis harta ribawi ini berbeda, maka jual belikanlah sesuai kehendakmu apabila dilakukan secara tunai".

2) Pendapat kedua: Halal (jual beli emas secara angsuran).

Ini adalah pendapat Ibnu Taimiyah dan Ibnu Qayim dan ulama kontemporer yang sependapat. Meskipun mereka berbeda dalam memberikan argumen (istidlal) bagi pandangan tersebut, hanya saja argumen yang menjadi landasan utama mereka adalah pendapat yang dikemukakan oleh Syeikh al-Islam Ibnu Taimiyah dan Ibnu Qayyim mengenai kebolehan jual beli perhiasaan (terbuat dari emas) dengan emas, dengan pembayaran tangguh.

\section{DAFTAR PUSTAKAN}

Abdul Wahab Khallaf, Mashadir al-Tasyri' al Islami fi ma la Naskh fih (Kuwait: Dar al- Qolam,1972) h. 50 .

Ahmad Hasan, Mata Uang Islami, Jakarta: PT Raja Grafindo Persada 2005 h. 11.

Aji Damanuri, Metodologi Penelitian Mu'amalah (Ponorogo : STAIN Po PRESS, 2010), hal.6

Al - Qur'an dan terjemahan, Al-Majid, Jakarta: Beras Al - Hadits Mahmud Syaltout, Al-Islam 'Aqidah wa Syari’ah, Kuwait: Dar al-Qalam 1966 h.11-13.
Amir Syarifuddin, UshulFiqh, h 144.

Amiruddin dan Zainal Asikin, Pengantar Metode Penelitian Hukum (Jakarta: Raja Grapindo Persada,2004), hal.30.

Badawi al-Khalafi, 'Abdul Azhim, Al- Wajiz Fi Fiqhis Sunnah wal Kitabil 'Aziz, Jakarta: Pustaka As-Sunnah, 2011.

Dewan Syariah Nasional MUI, Fatwa Nomor 77/DSN-MUI/V/2010 Tentang Jual Beli Emas Secara Tidak Tunai Wardi Bahtiar, Metode Penelitian Ilmu Dakwah, Jakarta: Logos 2001 h. 1.

Dr.Sami suwaylim, Qadhayaa Fil Iqtishad Wat Tamwil Islami, h. 37.

Fandy Tjiptono, Pemasaran Jasa, (Jatim: Banyumedia Publishing, 2005), edisi pertama.

Frank J Bruno, Kamus Istilah Kunci Psikologi, (Yogyakarta: Kanisius, 1989), h.134.

Hendi Suhendi, Fiqh Muamalah, Jakarta: Raja Grafindo Persada 2005 h. 68-69.

Mustafa Edwin Nasution, dkk., Pengenalan Eksklusif Ekonomi Islam, Jakarta: Kencana, 2007 h. 242.

Nasrun Haroen, Fiqh Muamalah, Jakarta: Gaya Media Pratama 2000 h. 111.

Natadipurba Chandra, Ekonomi Islam 101, Bandung: PT. Mobidelta Indonesia 2016 h. 231.

Nawawi, Ismail, Fikih Muamalah Klasik dan Kontemporer, Bogor: Ghalia Indonesia, 2017 h.72.

Nazir Mohammad, Metode Penelitian, Jakarta: Ghalia Indonesia 1998 h. 74.

Pengusaha Muslim. "Uang kertas Haram? Riba Pun Ada di Dinar dan Dirham", Edisi 28.

Pengusaha Muslim. "Halal - Haram Bisnis Online", Edisi 31.

Pusat Pembinaan dan Pengembangan Bahasa, Kamus Besar Bahasa Indonesia, (Jakarta, Balai Pustaka).

Rahmawati, Tresna, "Pengaruh Produk Pegadaian Syariah (Tabungan Emas) Terhadap 
Peningkatan Kesejahteraan Nasabah", Skripsi tidak diterbitkan, Jurusan Ekonomi Program Studi Ekonomi Syariah Sekolah Tinggi Agama Islam (STAI) Pelita Bangsa, Bekasi, 2017.

Saifudin Anwar, Metode Penelitian, Yogyakarta: Pustaka Pelajar 1998 h. 91.

Sugiono, Memahami Penelitian Kualitatif, Bandung: Alfabeta, 2005 h. 41.

Suharsimi Arikunto, Prosedur Penelitian, Jakarta: Rineika Cipta 2006 h. 158.

Suharsimi Arikunto, Prosedur Penelitian: Suatu Pendekatan Praktek, Jakarta: Rineika Cipta 1993 h. 131.

Sutrisno Hadi, Metodologi Research (Yogykarta: Andi Offset, 1990\}. Hlm 9.
Suwanda, Indra, "Analisis Implementasi Fatwa DSN-MUI No. 77/DSN-MUI/V/2010 Tentang Jual Beli Emas Secara Tidak Tunai", Skripsi tidak diterbitkan Jurusan Mu'amalah Fakultas Syari'ah Universitas Islam Negeri Raden Intan Lampung, Lampung, 2018

Suwaylim, Dr.Sami, Qadhayaa Fil Iqtishad Wat Tamwil Islami, h. 37.

Syafii Antonio, Muhammad, Bank Syariah Dari Teori Ke Praktik, Jakarta: Gema Insani 2001 h. 4.

Tarmidzi, Dr. Erwandi, Harta Haram Muamalat Kontemporer, Bogor: PT. Berkat Mulia Insani, 2018. 